\title{
Neutron Activation Analysis of Normal and Cadmium Injected Rat Liver Using Ammonium Pyrrolidinedithiocarbamate Extraction
}

\author{
Masaki SHINoGI, Kayoko FuKudA, Miyuki NAKAZAwA \\ and Itsuhiko MORI \\ Kobe Women's College of Pharmacy \\ Motoyamakita-machi, Higashinada-ku, Kobe-shi 658 \\ Received April 21, 1980
}

\begin{abstract}
A radiochemical group separation using APDC extraction was applied to the neutron activation analysis of normal and cadmium injected rat liver. In order to optimize determinations of induced radionuclides with various half lives, the gamma-ray spectra were obtained after various decay times. Eight elements, $\mathrm{Cd}, \mathrm{Co}, \mathrm{Cu}, \mathrm{Fe}, \mathrm{Mn}, \mathrm{Mo}, \mathrm{Se}$ and $\mathrm{Zn}$, were determined from rat liver samples within 12 day after irradiation. Although $\mathrm{Cd}, \mathrm{Cu}$ and $\mathrm{Mo}$ in normal rat liver could not be detected by nondestructive method, they could be determined after the extraction.

The tendency was seen that the concentration of all the elements as mentioned above are increased by cadmium injection. In particular, zinc and copper exhibited high values.
\end{abstract}

Key Words: neutron activation analysis, rat liver, ammonium pyrrolidinedithiocarbamate, solvent extraction, cadmium

\section{Introduction}

In recent years, the development of $\mathrm{Ge}(\mathrm{Li})$ detectors with high resolution has made the instrumental determination very useful in neutron activation analysis of biological materials. About thirty elements can be determined by the nondestructive method, but some elements can not be detected due to the disturbance of sodium, phosphorus or bromine present in biological materials. In order to remove those disturbing elements, many post-irradiation radiochemical group separation methods ${ }^{1)}$ with some chemical separation, such as precipitation, ion-exchange, solvent extraction and others, have been proposed. The solvent extraction method using organic chelate reagents become more effective due to its rapidity and selectivity. Ammonium pyrrolidinedithiocarbamate (abbreviated as APDC) is one of the most important reagents among generally applicable reagents, such as oxine, dithizone, cupferron or others. The APDC chelate compounds of about thirty elements have been known ${ }^{2}$ in which transition elements important in biological problems are all included. The application of a new radiochemical group separation method using APDC reagent in the extraction procedure in neutron activation analysis has recently been reported by Kusaka et al. ${ }^{3)}$. The validity of the method has been demonstrated by analyzing the NBS standard reference materials.

In the present study, this method has been applied to neutron activation analysis of normal and cadmium injected rat liver. The eight elements, Cd, Co, Cu, Fe, Mn, Mo, Se and $\mathrm{Zn}$, are determined from rat liver samples. In particular, the analytical results of $\mathrm{Cd}, \mathrm{Cu}$ and $\mathrm{Mo}$ in normal rat liver, which could not be detected by the nondestructive method reported previous$1 y,{ }^{4)}$ can be obtained.

\section{Experimental}

2.1 Preparation of the samples and standards

Six male rats of Wistar strain about $200 \mathrm{~g}$ were divided into two groups. One group was killed without cadmium injection. The other group was injected subcutaneously in the interscapular region with $0.5 \mathrm{mg} \mathrm{Cd} / \mathrm{kg}$ body weight as an isotonic saline solution of cadmium chloride of $0.1 \mathrm{mg} \mathrm{Cd} / \mathrm{m} l$. Injections were made three times on alternate days. The all animals 
were sacrificed by decapitation. The liver of these rats were removed, washed in distilled water, lyophilized and crushed by agate mortar.

NBS Bovine Liver (SRM-1577) was used as a multielemental irradiation standard, because the concentrations of seven elements, $\mathrm{Cd}, \mathrm{Co}$, $\mathrm{Cu}, \mathrm{Fe}, \mathrm{Mo}, \mathrm{Se}$ and $\mathrm{Zn}$, in Bovine Liver are higher than in Orchard Leaves.

The all samples and standards were dried in air oven at $85^{\circ} \mathrm{C}$ for 4 hours prior to irradiation, and $500 \mathrm{mg}$ of each sample was packed in polyethylene sheets.

\subsection{Neutron irradiation}

Samples and standards were contained in a polyethylene capsule and neutron irradiated for one hour at the pneumatic irradiation facility of the Kyoto University Reactor with an estimated thermal neutron flux of $2.3 \times 10^{13} n \cdot \mathrm{cm}^{-2} \cdot \mathrm{s}^{-1}$.

\subsection{Radiochemical separation procedure}

Each of the samples and standards irradiated was transferred into a $200 \mathrm{~m} l$ distillation flask and one $\mathrm{m} l$ of the carrier solution was added to it. The carrier solution is a mixture of $\mathrm{Cu}, \mathrm{Mn}$, $\mathrm{Fe}, \mathrm{Zn}$ and Cd solutions, and contains $20 \mu \mathrm{g} /$ $\mathrm{m} l$ of each element. The samples were mineralized in a wet way by a mixture of $2 \mathrm{~m} l$ of conc. $\mathrm{H}_{2} \mathrm{SO}_{4}$ and $3-5 \mathrm{~m} l$ of conc. $\mathrm{HNO}_{3}$. After removal of the excess $\mathrm{HNO}_{3}$ by evaporation, the bromine activity was completely removed by adding one $\mathrm{m} l$ of $10 \% \mathrm{KBr}$ solution and reevaporating to $\mathrm{SO}_{3}$ fuming. All the distillate was introduced into a $20 \mathrm{~m} l$ of $5 \mathrm{~N} \mathrm{NaOH}$ solution through a Liebig condenser to absord halogens.

Forty $\mathrm{m} l$ of $\mathrm{H}_{2} \mathrm{O}, 5 \mathrm{~m} l$ of $2 \mathrm{M}$ ammonium acetate solution and $5 \mathrm{ml}$ of $2 \%$ APDC solution were added to the resultant sample solution. And then the solution was adjusted to $4.0 \mathrm{pH}$ by the addition of $\mathrm{NH}_{4} \mathrm{OH}$ or $\mathrm{HCl}$, and extracted by $10 \mathrm{~m} l$ of $\mathrm{CHCl}_{3}$ Aqueous Phase was again extracted with $10 \mathrm{~m} l$ of $\mathrm{CHCl}_{3}$. Organic Phases were combined and shaken with $11 \mathrm{~m} l$ of an aqueous solution containing $10 \mathrm{ml}$ of $1 M \mathrm{NaCl}$ and one $\mathrm{m} l$ of $2 \%$ APDC solution to wash out any remaining sodium activity. Next, Aqueous Phase was adjusted to $7.0 \mathrm{pH}$ with $\mathrm{NH}_{4} \mathrm{OH}$ and the manganese activity was separated into $\mathrm{CH}$ -
$\mathrm{Cl}_{3}$ phase by the same procedure as mentioned above. Both Organic Phases were combined and then evaporated on a hot plate to dryness. The residue was dissolved in one $\mathrm{m} l$ of conc. $\mathrm{HNO}_{3}$, and the solution volume was made up to $7 \mathrm{~m} l$ by adding $1 N \mathrm{HCl}$ for the radioactivity measurement.

\subsection{Measurement of gamma activity}

Sample solutions after the radiochemical separation were counted with a coaxial $\mathrm{Ge}(\mathrm{Li})$ detector (FWHM $2.0 \mathrm{keV}$ at $1.332 \mathrm{MeV}$ ) coupled to a 4096 channel pulse-height analyzer. For the purpose of comparison, one of the irradiated samples was also counted without any radiochemical separation. The gamma activity was measured for $3,000,6,000,10,000$ and 10,000 seconds after a decay of 10 hours, 3 days, 12 days and 30 days, respectively.

\section{Results and Discussion}

3.1 A comparison of gamma-ray spectrum

Typical gamma-ray spectra obtained from normal and cadmium injected rat liver with and without radiochemical separation are shown together with that of an aliquot of the aqueous phase after the radiochemical separation in Fig. 1,2 and 3 .

In Fig. 1, photo-peaks of ${ }^{69 m} \mathrm{Zn},{ }^{65} \mathrm{Zn},{ }^{64} \mathrm{Cu}$ and large photo-peaks of $847 \mathrm{keV}$ and $1811 \mathrm{keV}$ from ${ }^{56} \mathrm{Mn}$ in the radiochemically separated samples are identified. The peak of ${ }^{115} \mathrm{Cd}\left({ }^{115 m} \mathrm{In}\right.$; daughter nuclide of ${ }^{115} \mathrm{Cd}$ ) is also obvious in $\mathrm{Cd}$ injected rat liver. In the nondestructive method, large peaks of ${ }^{24} \mathrm{Na}$ and ${ }^{42} \mathrm{~K}$ and a small peak of ${ }^{56} \mathrm{Mn}$ are seen together with many peaks of ${ }^{82} \mathrm{Br}$.

It is shown in Fig. 1 that ${ }^{24} \mathrm{Na}$ and ${ }^{42} \mathrm{~K}$ were removed completely by this radiochemical separation method and that manganese was able to be determined.

In Fig. 2, longer-lived nuclides such as ${ }^{59} \mathrm{Fe}$, ${ }^{65} \mathrm{Zn}$ and ${ }^{60} \mathrm{Co}$, which can be barely determined after a 30-day decay on the nondestructive method, are detected in the samples separated. The peaks of ${ }^{99} \mathrm{Mo}(740 \mathrm{keV}$ and $780 \mathrm{keV})$ and ${ }^{99 m} \mathrm{Tc}(1.40 \mathrm{keV})$, which is daughter nuclide of ${ }^{99} \mathrm{Mo}$, are also detected. The total count of ${ }^{115} \mathrm{Cd}\left({ }^{115 m} \mathrm{In}\right)$ is higher than that in Fig. 1. The 
peaks of ${ }^{69 m} \mathrm{Zn}(439 \mathrm{keV})$ and ${ }^{64} \mathrm{Cu}(1346$ $\mathrm{keV}$ ) are observed again. On the other hand, any other nuclides, expect ${ }^{24} \mathrm{Na}$, ${ }^{42} \mathrm{~K}$ and ${ }^{82} \mathrm{Br}$, are not detected in the normal rat liver samples by the nondestructive method. But in the Cd injection samples, the peaks of ${ }^{115} \mathrm{Cd}\left({ }^{115 m} \mathrm{In}\right)$ are detected. ${ }^{76} \mathrm{As}$ is observed in both organic and aqueous phase after the radiochemical separation, so As cannot be determined.

From Fig. 2, Cu, $\mathrm{Cd}$ and $\mathrm{Mo}$ are able to be determined.

It can be seen in Fig. 3 that background spectrum of low energy region due to bremsstrahlung radiation of ${ }^{32} \mathrm{P}$ betaray is decreased by the extraction, because phosphorus is removed by this radiochemical separation method. It is possible to measure the peaks of ${ }^{75} \mathrm{Se}$. In the gamma-ray spectrum of the nondestructive method, many peaks of ${ }^{82} \mathrm{Br}$ are observed again, and also the peaks of ${ }^{75} \mathrm{Se},{ }^{134} \mathrm{Cs},{ }^{86} \mathrm{Rb},{ }^{59} \mathrm{Fe},{ }^{65} \mathrm{Zn}$ and ${ }^{60} \mathrm{Co}$ are detected. On the other hand, ${ }^{134} \mathrm{Cs}$ and ${ }^{86} \mathrm{Rb}$ can be detected in the aqueous phase sample.

After a decay of $\mathbf{3 0}$ days, the gammaray spectra obtained from cadmium injected rat liver sample become similar to those from normal rat liver sample, because all peaks of $\mathrm{Cd}$ disappear. The longer-lived nuclides can be determined from the nondestructive spectrum, but counting error, especially at low energy side, is large owing to the bremsstrahlung of ${ }^{32} \mathrm{P}$.

It may be concluded from the above discussion that the gamma-ray spectra of the separated fraction can be measured on the day of the irradiation for $\mathrm{Mn}$; after a 3-day decay for $\mathrm{Cu}, \mathrm{Cd}, \mathrm{Mo}, \mathrm{Co}$, $\mathrm{Fe}$ and $\mathrm{Zn}$; and after a 12-day decay for Se. Thus, seven elements other than Se can be determined within only 3 days after neutron irradiation, while a 30-day decay is required to determine these elements by the nondestructive method.

It can also be concluded that by this separation biologically essential or toxic

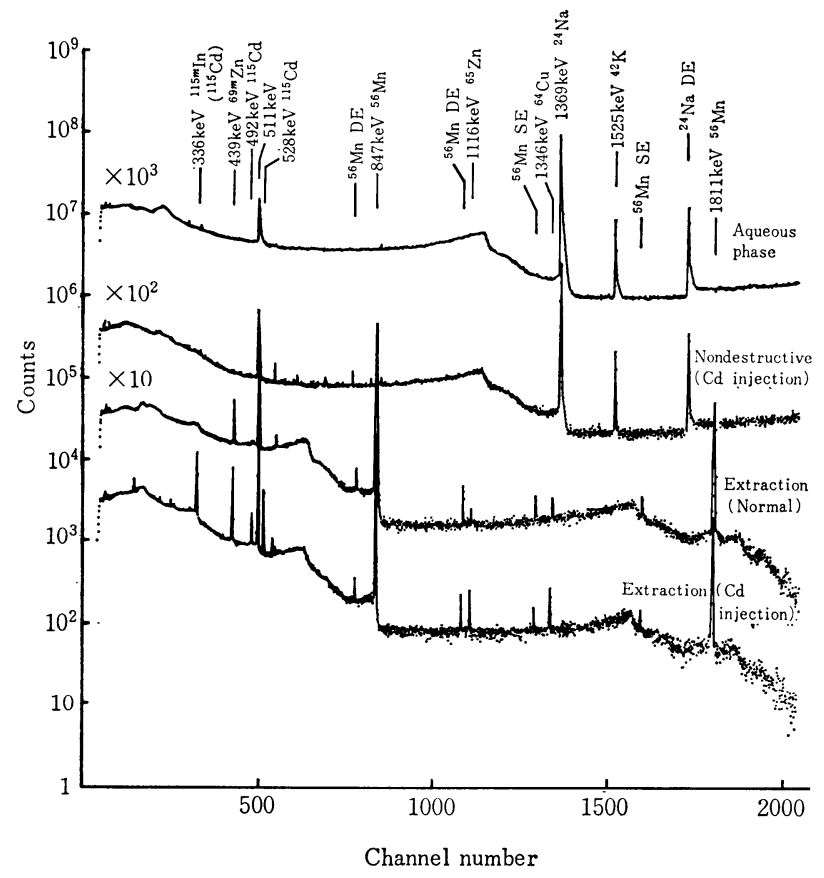

Fig. 1 Typical gamma-ray spectra of normal and $\mathrm{Cd}$ injected rat liver irradiated for one hour and counted for 3000 seconds after a decay of 10 hours.

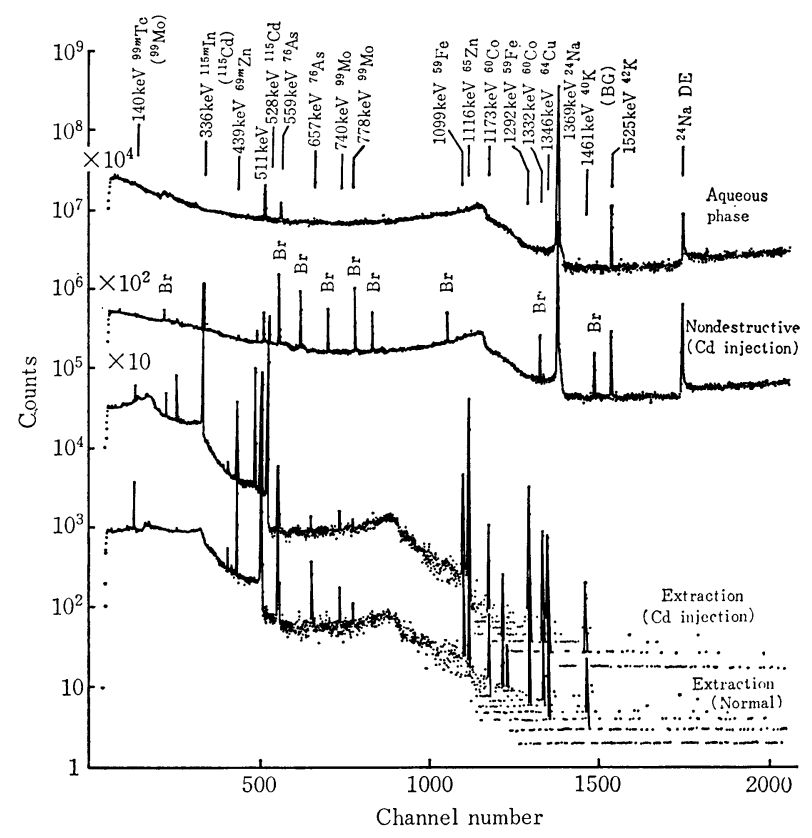

Fig. 2 Typical gamma-ray spectra of normal and $\mathrm{Cd}$ injected rat liver irradiated for one hour and counted for 6000 seconds after a decay of 3 days. 
transition elements are extracted into the organic phase leaving alkali elements, in the aqueous phase.

\subsection{Analysis of normal and cadmium injected rat liver}

The results of the eight elements such as $\mathrm{Cd}, \mathrm{Co}, \mathrm{Cu}, \mathrm{Fe}, \mathrm{Mn}$, $\mathrm{Mo}, \mathrm{Se}$ and $\mathrm{Zn}$ are given in Table 1. The present results for normal rat liver are compared with our former results obtained by the nondestructive method ${ }^{4)}$. By the use of radiochemical separation using APDC extraction, $\mathrm{Cd}, \mathrm{Cu}$ and $\mathrm{Mo}$ in the normal rat liver can be determined. The values of $\mathrm{Fe}, \mathrm{Mn}, \mathrm{Se}$ and $\mathrm{Zn}$ are in fair agreement with those by the nondestructive method, but the agreement in Co is not so good.

On the other hand, in the cadmium in jected rat liver, the above eight elements were also determined. It has been found that there is a tendency for the concentration of the eight elements to increase caused by cadmium injection. In partic-

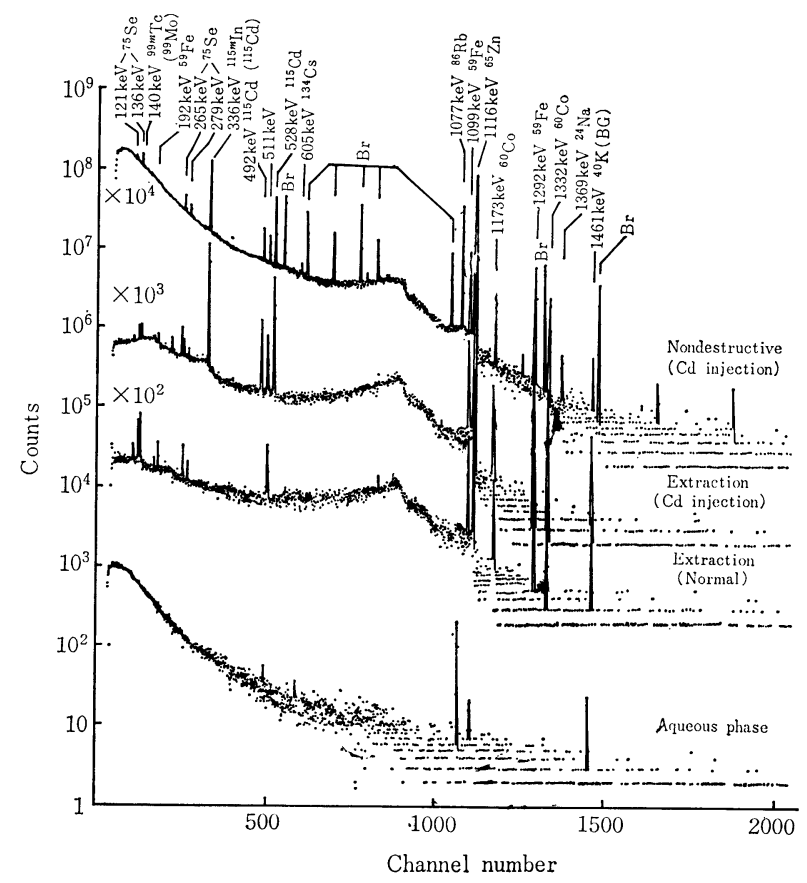

Fig. 3 Typical gamma-ray spectra of normal and $\mathrm{Cd}$ injected rat liver irradiated for one hour and counted for 10000 seconds after a decay of 12 days.

Table 1 Analysis of normal and $\mathrm{Cd}$ injected rat livers

\begin{tabular}{|c|c|c|c|c|c|c|c|}
\hline \multirow{2}{*}{ Element } & \multirow{2}{*}{$\begin{array}{l}\text { Nuclide of } \\
\text { determination }\end{array}$} & \multirow{2}{*}{ Half life } & \multirow{2}{*}{$\begin{array}{l}\gamma \text {-ray } \\
\text { energy } \\
(\mathrm{keV})\end{array}$} & \multicolumn{2}{|c|}{ Normal (ppm) } & \multirow{2}{*}{$\begin{array}{l}\text { Cd injection } \\
\quad(\mathrm{ppm})\end{array}$} & \multirow{2}{*}{$\frac{\text { Cd inj. }}{\text { Normal }}$} \\
\hline & & & & This study & Nondestructive & & \\
\hline $\mathrm{Cd}$ & ${ }^{115 m} \operatorname{In}\left({ }^{115} \mathrm{Cd}\right)$ & $\begin{array}{l}4.48 \mathrm{~h} \\
(53.4 \mathrm{~h})\end{array}$ & 335 & $0.048 \pm 0.012$ & ND & $85 \pm 11$ & $1170 \pm 500$ \\
\hline Co & ${ }^{60} \mathrm{Co}$ & $5.26 \mathrm{y}$ & 1173 & $0.125 \pm 0.011$ & $0.38 \pm 0.12$ & $0.194 \pm 0.025$ & $1.55 \pm 0.24$ \\
\hline $\mathrm{Cu}$ & ${ }^{64} \mathrm{Cu}$ & $12.8 \mathrm{~h}$ & 1346 & $12.3 \pm 0.2$ & ND & $17.8 \pm 0.7$ & $1.45 \pm 0.06$ \\
\hline $\mathrm{Fe}$ & ${ }^{59} \mathrm{Fe}$ & $45.6 \mathrm{~d}$ & 1099 & $230 \pm 20$ & $260 \pm 40$ & $320 \pm 50$ & $1.39 \pm 0.25$ \\
\hline $\mathrm{Mn}$ & ${ }^{56} \mathrm{Mn}$ & $2.58 \mathrm{~h}$ & 847 & $6.7 \pm 0.2$ & $6.3 \pm 1.5$ & $6.88 \pm 0.04$ & $1.03 \pm 0.03$ \\
\hline Mo & ${ }^{99 m} \mathrm{Tc}\left({ }^{99} \mathrm{Mo}\right)$ & $\begin{array}{c}6.05 \mathrm{~h} \\
(66.0 \mathrm{~h})\end{array}$ & 140 & $1.47 \pm 0.13$ & ND & $1.60 \pm 0.08$ & $1.09 \pm 0.11$ \\
\hline Se & ${ }^{75} \mathrm{Se}$ & $120.4 \mathrm{~d}$ & 265 & $2.0 \pm 0.5$ & $2.6 \pm 0.6$ & $4.1 \pm 1.7$ & 2. $1 \pm 1.0$ \\
\hline $\mathrm{Zn}$ & ${ }^{65} \mathrm{Zn}$ & $245 \mathrm{~d}$ & 1116 & $85 \pm 5$ & $88 \pm 15$ & $191 \pm 8$ & $2.3 \pm 0.2$ \\
\hline
\end{tabular}

ND: Not detected.

ular, the relative concentrations of zinc and copper exhibit high values. The increase of zinc and copper concentrations is considered to have some relation with the production of cadmium binding protein (metallothioneine) in liver by in jection of cadmium.

Further study of the metallothioneine, which binds with many metal elements, by neutron activation analysis should be required in studing the physiological and pathological roles of trace elements in biological materials.

\section{References}

1) D. De Soete, R. Gijbels and J. Hoste: "Neutron Activation Analysis," Vol. 34, ed. by P.J. Elving and I.M. Kolthoff, John Wiley and Sons, Inc., pp. 311-92 London (1973) 
2) H. Malissa and E. Schoffmann: Mikrochim. Acta, 42, 187 (1955)

3) Y. Kusaka, H. Tsuji, Y. Tamari, T. Sagawa, S. Ohmori, S. Imai and T. Ozaki:
J. Radioanal. Chem., 37, 917 (1977)

4) M. Shinogi, K. Fukuda, M. Nakazawa and I. Mori: Chem. Pharm. Bull., 28, 2094 (1980)

要 旨

\title{
Ammonium Pyrrolidinedithiocarbamate 抽出を使用する正常ラット および Cd 投与ラット肝臓の中性子放射化分析
}

\author{
志野木正樹, 福田佳代子, 中澤三由紀, 森 五彦 \\ 神戸女子薬科大学 \\ 658 神戸市東灘区本山北町4-19-1
}

\begin{abstract}
APDC 抽出法を使用する放射化学的グループセパレーション法を正常ラットおよび Cd 投与ラッ ト肝藏の中性子放射化分析に応用した。種々の半減期をるつ誘導核種の最適な測定のために，種々 の隇衰時間の後に得られた

照射後 12 日以内に，ラット肝臓試料中の $\mathrm{Cd}, \mathrm{Co}, \mathrm{Cu}, \mathrm{Fe}, \mathrm{Mn}, \mathrm{Mo}, \mathrm{Se}, \mathrm{Zn}$ の 8 元素を測定した. 非 破壊法では検出されなかった正常ラット肝臟中の $\mathrm{Cd}, \mathrm{Cu}, \mathrm{Mo}$ の分析值を得ることができた.

$\mathrm{Cd}$ を投与することによって，上記のすべての元素濃度は増加する傾向がある. とくに $\mathrm{Zn}$ と $\mathrm{Cu}$ は高い值を示した。
\end{abstract}

